\title{
Effect of litter on the surface runoff of a forest fragment in the Atlantic Forest
}

\author{
Aline Gonçalves Spletozer ${ }^{1} \oplus$, Lucas Jesus da Silveira' ${ }^{1}$, Rodolfo Alves Barbosa ${ }^{1 *} \oplus$, \\ Sergio Guedes Barbosa ${ }^{1} \oplus$, Herly Carlos Teixeira Dias ${ }^{1} \oplus$

\footnotetext{
${ }^{1}$ Federal University of Viçosa, Viçosa, MG, Brasil. E-mail: alinespletozer_afmt@hotmail.com; ljsfloresta@hotmail.com; rodolfo.ufv@gmail.com; sergioflora@hotmail.com; herlycarlostdias@gmail.com
}

ABSTRACT: The objective of study was to characterize the litter and quantify its effect on runoff during the dry and rainy season in a forest fragment of the Atlantic Forest. Six plots, three with and three without litter, were used to assess runoff. Runoff and open precipitation were measured after rain events and compared using the Wilcoxon test. Litter collection was performed to quantify it and measure its water retention capacity (WRC). The litter WRC was $3.75 \mathrm{~mm} \mathrm{~kg}^{-1}(5.44 \mathrm{~mm})$ and was in the retention range for tropical forests $(4.57-16.29 \mathrm{~mm})$. Total open precipitation was $1,013.47 \mathrm{~mm}$ and runoff values corresponded to 1.79 and $2.54 \%$ of open precipitation for plots with and without litter, respectively. The runoff of plots with litter was lower by $16.72 \%$, this was also recorded during the dry season. This lower runoff can be explained by the litter function of delaying and reducing runoff by protecting the soil from rain and increasing surface roughness. The presence of litter has reduced the runoff in the forest fragment at an early stage of regeneration in the Atlantic Forest.

Key words: forest hydrology; organic matter; surface water

\section{Efeito da serapilheira no escoamento superficial de um fragmento florestal na Mata Atlântica}

RESUMO: Os objetivos do estudo foram caracterizar a serapilheira e quantificar seu efeito no escoamento superficial durante a estação seca e chuvosa em um fragmento da Mata Atlântica. Seis parcelas, três com e três sem serapilheira, foram usadas para avaliar o escoamento superficial. O escoamento superficial e a precipitação aberta foram medidos após eventos de chuva e comparados pelo teste de Wilcoxon. A coleta de serapilheira foi realizada para quantificá-lo e medir sua capacidade de retenção de água $(\mathrm{CRH})$. A CRH da serapilheira foi de $3,75 \mathrm{~mm} \mathrm{~kg}{ }^{-1}(5,44 \mathrm{~mm})$ e estava na faixa de retenção de florestas tropicais (4,57-16,29 mm). A precipitação total aberta foi de $1.013,47 \mathrm{~mm}$ e os valores de escoamento corresponderam a 1,79 e 2,54\% da precipitação aberta para parcelas com e sem serapilheira, respectivamente. 0 escoamento superficial das parcelas com serapilheira foi $16,72 \%$ menor, o que também foi registrado durante a estação seca. Esse escoamento mais baixo pode ser explicado pela função da cama de retardar e reduzir o escoamento, protegendo o solo da chuva e aumentando a rugosidade da superfície. A presença de serapilheira reduziu o escoamento no fragmento florestal em um estágio inicial de regeneração na Mata Atlântica.

Palavras-chave: hidrologia florestal; matéria orgânica; água da superfície

\footnotetext{
${ }^{*}$ Rodolfo Alves Barbosa - E-mail: rodolfo.ufv@gmail.com (Corresponding author)

Associate Editor: Fernando José Freire
} 


\section{Introduction}

The presence of the forest is a benefit in maintaining the water quality of rivers (Abraham et al., 2017). The canopy is recognized for its function of intercepting rainfall in forest ecosystems (Gerrits et al., 2010), but the hydrological functions of the litter layer are neglected due to measurement difficulties (Walsh \& Voigt, 1977; Li et al., 2013).

The litter is considered as an effective coverage above the soil surface including leaves, flowers, fruits, bark, twigs, animal feces, and seeds (Dias et al., 2017). Despite the role of the litter in contributing to the geochemical cycle (Ali et al., 2017), promote soil protection against the impact of rainwater preventing erosion, improve the physical properties of the soil, among others (Li et al., 2014). The water dynamics of the litter layer is underestimated and even disregarded in hydrological studies (Gerrits et al., 2010).

The effectiveness of various surface coverings in reducing runoff and soil loss has been previously assessed (Gerrits et al., 2010; Li et al., 2014). Overall, the litter layer reduced runoff and sediment generation (Miyata et al., 2009; Li et al., 2014; Gomyo \& Kuraji, 2016). However, some results point to an increase in runoff due to the litter repellency to water, especially after drought (Burch et al., 1989; Coelho et al., 2005).

Resins, waxes, phenolic compounds and aromatic oils are released in the litter decomposition process due to their biochemical composition and the action of microorganisms which gives a strong ability to induce water repellency in the soil (Cesarano et al., 2016). This soil repellency or hydrophobicity can reduce water infiltration, increasing runoff (Burch et al., 1989). The quantification of the various hydrological effects of litter on water repellency in the field is still poorly studied (Vogelmann et al., 2015), most studies use simulated data in the laboratory ( Li et al., 2013), but direct results can be obtained in field trials to investigate the effect of litter on water losses (Liu et al., 2017).

The objective of this work was to characterize the litter and to quantify its effect on runoff during the dry and rainy season in an Atlantic Forest fragment in an early stage of regeneration.

\section{Materials and Methods}

\section{Study area}

The study was carried out in a 194 ha forest fragment $\left(20^{\circ} 48^{\prime} 0^{\prime \prime} \mathrm{S}\right.$ and $\left.42^{\circ} 51^{\prime} 20^{\prime \prime} \mathrm{W}\right)$ located in Viçosa, Minas Gerais, Brazil (Figure 1). The fragment consists of a mosaic with different successional stages of seasonal forest, with deciduous trees $(20 \%$ to $50 \%)$ that lose their leaves during the cold, dry winter (Silva Júnior et al., 2004; Marcilio-Silva et al., 2017). The experiment was installed in an initial regeneration area previously composed of pasture of Melinis minutiflora P. Beauv. abandoned since 1963 (Silva Júnior et al., 2004). The dominant genus in the area are: Protium, Senna, Nectandra, Trichilia, Myrcia, Casearia, Solanum and Cecropia (Pinto et al., 2013).

The climate is Cwa (Köppen), the annual precipitation and average annual temperature are $1,361 \mathrm{~mm}$ and $19.5^{\circ} \mathrm{C}$, respectively (Alvares et al., 2013). The soil is dystrophic RedYellow Latosol (FEAM, 2019).

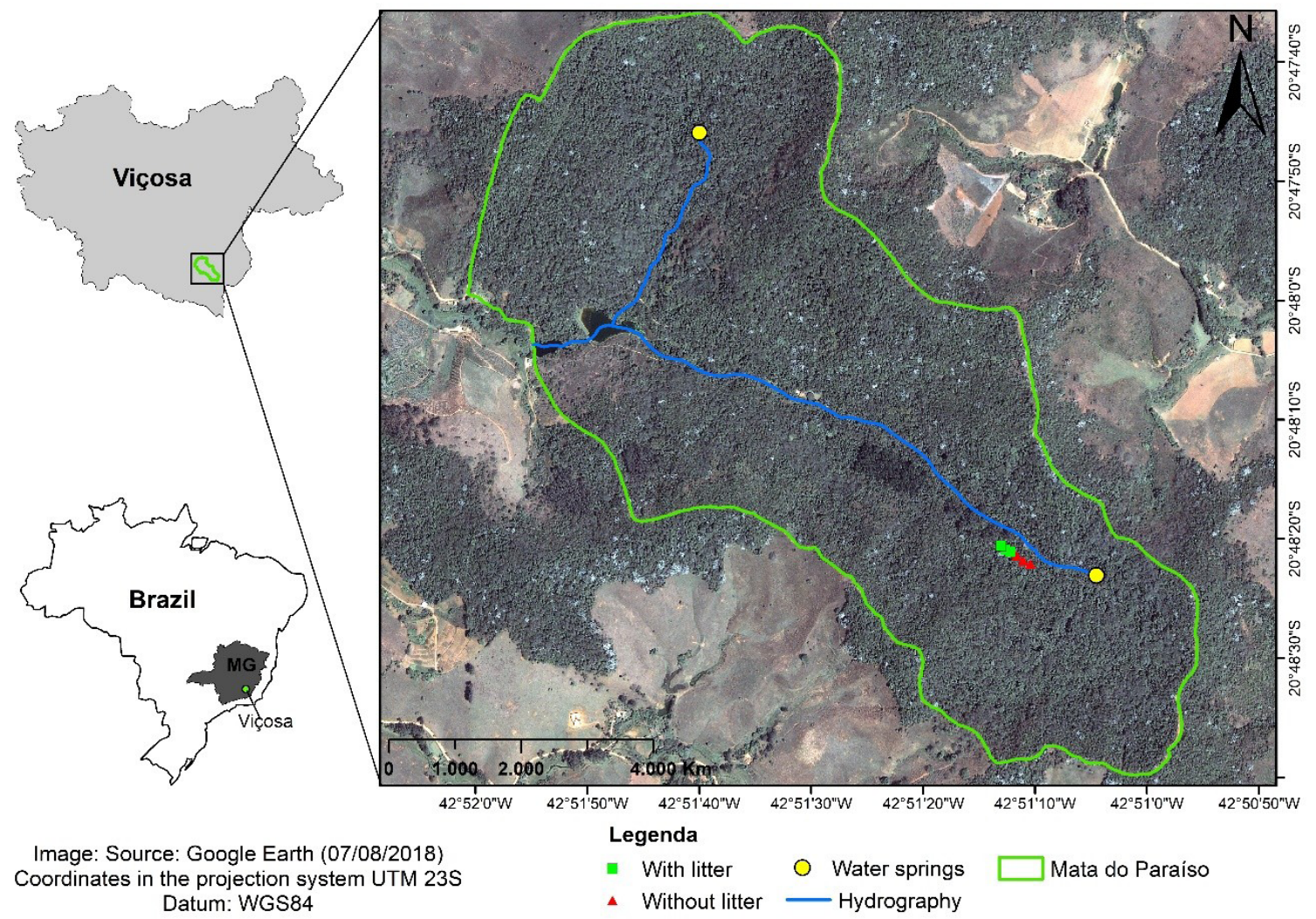

Figure 1. Location of sample units in the study area in the municipality of Viçosa, Minas Gerais, Brazil. 


\section{Characterization of litter}

The litter was collected in January 2015 at three points randomly launched close to the runoff plots, with the aid of a $0.25 \mathrm{~m}^{2}(0.5 \times 0.5 \mathrm{~m})$ template. The water retention capacity (WRC) of the litter was determined from the adaptation of the Blow method (1955). The saturated weight (SAW) was obtained by saturating the litter samples in water for 72 hours (in the original method was 90 minutes), then the excess water was drained in a sieve and the saturated litter was weighed. The dry weight (DRW) was obtained by drying the samples in an oven, with forced air circulation at $70^{\circ} \mathrm{C}$, until constant weight. WRC was calculated in millimeters (liters per template area) per kilogram of dry litter $\left(\mathrm{mm} \mathrm{Kg}^{-1}\right)$ : WRC = (SAW - DRW)/DRW (Blow, 1955). The litter stock of the forest fragment was estimated by extrapolation and presented in megagrams per hectare $\left(\mathrm{Mg} \mathrm{ha}^{-1}\right)$.

\section{Precipitation and runoff measurements}

Total rainfall was measured during 2015, after each rain event. The open precipitation was obtained in a rain gauge with a $167 \mathrm{~cm}^{2}\left(0.0167 \mathrm{~m}^{2}\right)$ rainwater catchment area installed in a tower above the forest canopy. The value of open precipitation in $\mathrm{mm}(\mathrm{P})$ was calculated by the relationship between the volume collected in the pluviometer in liters (PV) and the rainwater capture area in $\mathrm{m}^{2}$ (CA) according to Equation 1 (WMO, 2018).

$$
\mathrm{P}=\frac{\mathrm{PV}}{\mathrm{CA}}
$$

Treatment (with litter) and control (bare soil) plots with three replicates were installed to measure surface runoff. These plots were installed on $23 \%$ slopes and surrounded by $1.2 \mathrm{~mm}$ thick metal sheets inserted into the ground at a depth of 5-7 cm (Figure 2). The drained runoff was collected by gutter and stored in a 40-liter container. Water levels were measured at each rain event between January and December 2015 using a graduated cylinder and graduated bucket. The total litter deposited on the soil in three random plots (areas of $13.71,14.79$ and $14.26 \mathrm{~m}^{2}$ ) was discarded and in three other plots the litter was maintained (areas of 14.86, 14.25 and $13.77 \mathrm{~m}^{2}$ ). Surface runoff in $\mathrm{mm}(\mathrm{SR})$ was calculated by the relationship between the volume collected in liters (V) and the plot area in $\mathrm{m}^{2}(\mathrm{~A})$ according to Equation 2 (Miller, 1994).

$$
\mathrm{SR}=\frac{\mathrm{V}}{\mathrm{A}}
$$

The runoff coefficient (RC) was determined by the ratio between the volume of surface runoff (SR) and the volume of precipitated water (PA) and multiplied by 100 to obtain the percentage runoff (PR in \%) (Miller, 1994).

\section{Statistical analysis}

The average data of plots with and without litter were plotted monthly for graphical analysis. The Wilcoxon test

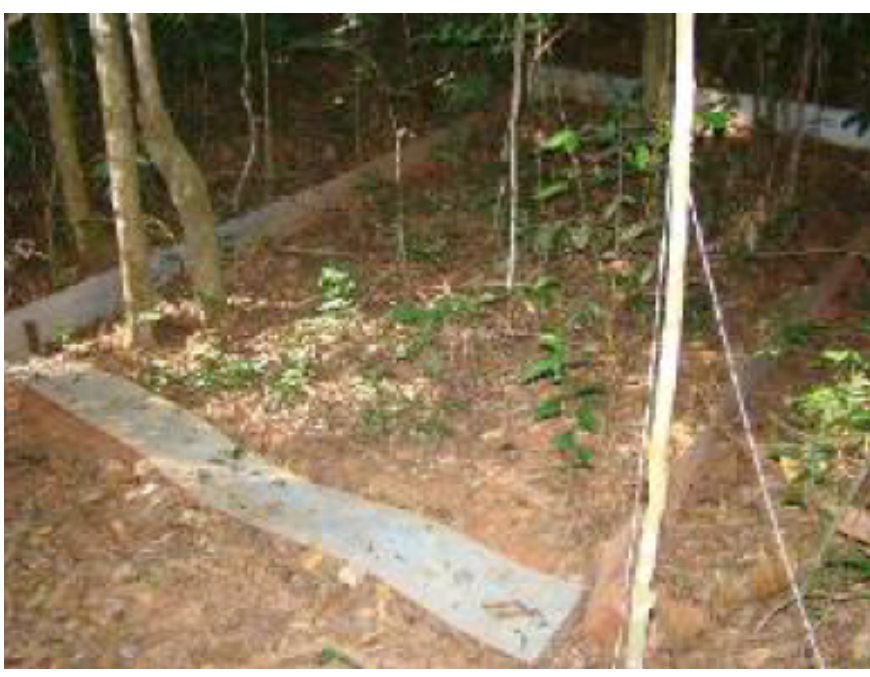

Figure 2. Plot for collecting runoff in the study area in the municipality of Viçosa, Minas Gerais, Brazil.

for paired data was applied to test whether the differences between the treatment (with litter) and control (bare soil) plots were statistically significant $(p$-value $=0.05)$ for the annual average and in the dry season (April-September) and rainy (October-March). A simple linear regression and the determination coefficient were used to explain the differences and relate the characteristics of the rains to the surface runoff. Statistical analyzes were performed using software R ( $R$ Core Team, 2018).

\section{Results and Discussion}

Rainfall

A total of $1,014 \mathrm{~mm}$ of rainfall was recorded during the study period, $34 \%$ less than the long-term annual average (Alvares et al., 2013). The monthly pattern of precipitation differed from the historical average, climatological normals (Figure 3). The volume of rainfall in January was about $98 \%$ less than the long-term average, while in September and

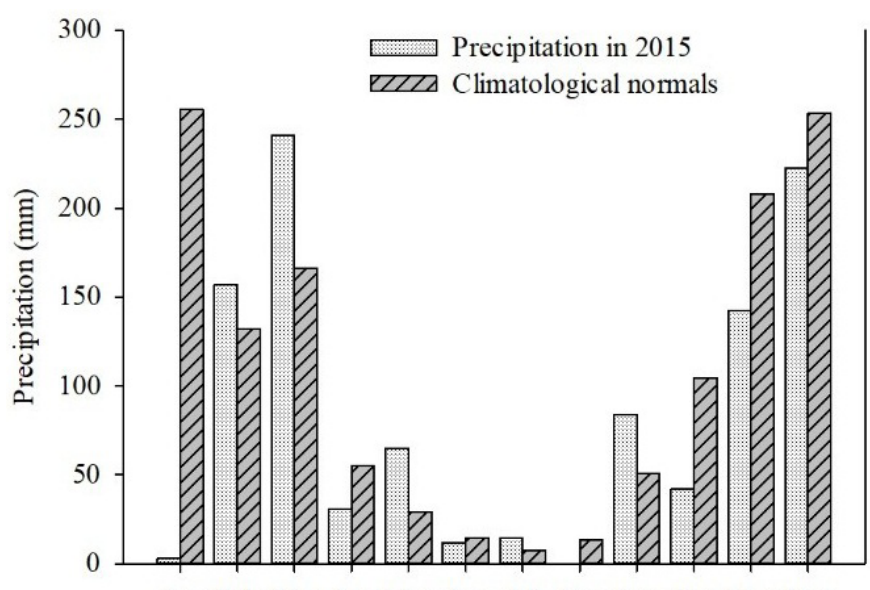

Jan Feb Mar Apr May Jun Jul Aug Sep Oct Nov Dec

Figure 3. Distribution of total monthly rainfall for the forest fragment of Atlantic Forest in 2015. The climatological normals (accumulated precipitation) correspond to the 19812010 period (INMET, 2018). 
March it was around 39 and 31\% higher. March and December were the rainiest months, registering approximately $46 \%$ of the total rainfall. The maximum volume of water per collection also occurred in these two months.

Climatic phenomena in South America were responsible for changes in the rain regime and temperature rise, including between 2014-2015 (Muñoz et al., 2016), explaining the differences between the monthly rainfall observed for the year 2015 and the climatological normal.

\section{Litter characteristics}

The water retention capacity of the litter (WRC) was 5.44 $\mathrm{mm}$ or $3.75 \mathrm{~mm} \mathrm{Kg}^{-1}$, when expressed as the weighted mean storage capacity per unit dry mass. The saturated and dry litter mass was $6.89 \mathrm{~kg} \mathrm{~m}^{-2}\left(68.97 \mathrm{Mg} \mathrm{ha}^{-1}\right)$ and $1.45 \mathrm{~kg} \mathrm{~m}^{-2}$ (14.52 $\left.\mathrm{Mg} \mathrm{ha}^{-1}\right)$, respectively.

The WRC of the litter found plays a significant role in the transformation of rainwater, since, by storing it, it allows water to infiltrate the soil instead of evaporating (loss) (Li et al., 2013). The WRC was at the lower limit of the range (4.57$16.29 \mathrm{~mm}$ ) reported for tropical litter in four forests in the Amazon (Marin et al., 2000). This result can be understood in terms of the litter necromass being much higher (3.27-9.81 $\mathrm{kg} \mathrm{m}^{-2}$ ) in the forest plots of the Amazon (Marin et al., 2000) in relation to the fragment of the present work in stage initial regeneration $\left(1.45 \mathrm{~kg} \mathrm{~m}^{-2}\right.$ ). However, the amount of litter is higher than that found in 5-year forest plantations (0.96$3.68 \mathrm{~kg} \mathrm{~m}^{-2}$ ) in Panama (Park et al., 2010). This difference is easily understood when it is considered that litter samples in plantations are monospecific, or almost, while litter layers in forest will comprise mixtures of a wide variety of species (Park et al., 2010), as found for different species in the Jiu Feng National Forest Park in China the broadleaf litter with larger leaf area, pore size and at the contact angle absorbed more water (2.65 times) than the same litter mass made up of various species (Li et al., 2013). The results indicated that the litter composition played an important role in the WRC, as well as that the litter mass has a strong influence on the WRC (Li et al., 2013). Thus, the percentage of rain retained by the litter shows an inverse relationship with the amount of rainwater losses (Walsh \& Voigt, 1977).

The litter stock in the forest fragment was $14.50 \mathrm{Mg} \mathrm{ha}^{-1}$. This value found is greater than that for a fragment of the same forest typology (seasonal semideciduous forest) with 1 ha and 30 years of restoration by ecological succession composed of pioneer and early secondary species, whose value was 5.15 $\mathrm{Mg} \mathrm{ha}^{-1}$ (Mateus et al., 2013), indicating that the present area has greater biomass, and according to Mateus et al. (2013) can be explained by the increase in diversity of species (Park et al., 2010) and the size of the fragment that influences the successional advance (Liu et al., 2019), although both are in primary succession.

\section{Surface runoff}

The annual surface runoff in plots with litter layer was significantly reduced, being 1.2 times less (16.72\%) than in plots without litter. The percentage runoff was $1.79 \%$ (18.18 $\mathrm{mm}$ ) of the $1,014 \mathrm{~mm}$ of rainfall in plots with litter and less than $2.54 \%$ ( $21.83 \mathrm{~mm}$ ) of plots without litter (Table 1).

The lowest surface runoff in the litter plots was due to the protection of the soil provided by the litter layer, which, by dampening the impact of the raindrop and increasing the surface roughness, reduces and delays the surface runoff and allows more time for the infiltration of soil water ( $\mathrm{Li}$ et al., 2014; Gomyo \& Kuraji, 2016; Liu et al., 2017). Our results of percentage runoff were lower than those reported in the litter of the species of the Jiu Feng National Forest Park in China (29.5-31.3\%), even though the litter cover had an impact in reducing runoff in both studies, other factors, how precipitation and intensity of rain should also be taken into account, as our work was under natural rain (Li et al., 2014). However, our results are similar to those observed in eucalyptus cultivation with a slope between $12-21 \%$, in which the treatment with forest residue on the soil (branches, bark and leaves from mechanized tree harvesting) was inferior (PR $=1.6 \%)$ treatment without residue (PR $=2.9 \%$ ) (Baptista \& Levien, 2010). The results are also close to that measured in the same forest fragment, between 2010-2011, whose runoff coefficient was $2.08 \%$ with litter (Lorenzon et al., 2015) and that measured in an agroforestry system in which the runoff reduced 1.7 times in the plots with litter layer in relation to the bare soil (Liu et al., 2017).

Highest surface runoff for litter treatment was observed in October, the first month of the wet season, and February, both preceded by a dry month (Figure 4). The highest surface runoff in October is due to the fact that this is the first month after the change of season, characteristic of the local climate with dry winters. However, January rainfall was well below the historical average (Figure 3 ) due to the consequences of the climatic phenomenon (Muñoz et al., 2016), therefore, February also preceded a drought period.

The highest runoff observed in February and October for the litter plots suggests the hydrophobic behavior of this material after a dry period (Burch et al., 1989; Coelho et al., 2005). However, the effect of water repellency is quickly reversed by wetting the litter with the beginning of the rainy season, because its action occurs, mainly, in the reduction of

Table 1. Open and annual rainfall (PA in $\mathrm{mm}$ ), surface runoff ( $S R$ in $\mathrm{mm}$ ) and percentage runoff (PR in \%) in plots with and without litter, in a forest fragment of Atlantic Forest.

\begin{tabular}{|c|c|c|c|c|c|c|c|c|c|}
\hline \multirow{2}{*}{ Plots } & \multicolumn{3}{|c|}{ Yearly } & \multicolumn{3}{|c|}{ Dry season } & \multicolumn{3}{|c|}{ Rainy season } \\
\hline & PA & SR & PR & PA & SR & RC & PA & SR & PR \\
\hline With & \multirow{2}{*}{1,014} & $18.18 \mathrm{a}$ & $1.79 \mathrm{a}$ & \multirow{2}{*}{205.69} & $3.79 \mathrm{a}$ & $1.84 \mathrm{a}$ & \multirow{2}{*}{807.78} & $14.40 \mathrm{a}$ & $1.78 \mathrm{a}$ \\
\hline Without & & $21.83 \mathrm{~b}$ & $2.54 \mathrm{~b}$ & & $6.16 \mathrm{~b}$ & $2.99 \mathrm{~b}$ & & $15.55 \mathrm{a}$ & $1.92 \mathrm{a}$ \\
\hline
\end{tabular}

Values followed by the same letter in the column do not differ by the Wilcoxon test at $5 \%$ probability. 


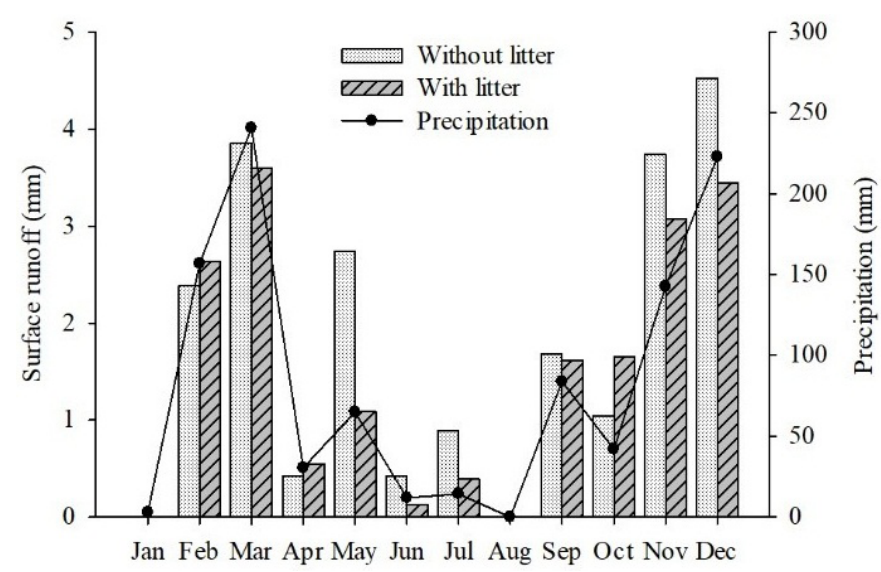

Figure 4. Surface runoff (SR) in plots without and with litter in a forest fragment of Atlantic Forest, Viçosa, Minas Gerais, Brazil.

the initial infiltration rates (Burch et al., 1989) and its effect on the annual scale is not noticeable (Table 1).

Surface runoff in plots with a litter layer was significantly reduced in the dry season (April-September) when compared to bare soil (Table 1). During the dry season the fall of plant material in the soil, which will compose the litter, is considerably abundant (Selle, 2007), reinforcing the effect of the litter in maximizing infiltration by delaying and reducing the runoff of water on the surface (Li et al., 2014; Gomyo \& Kuraji, 2016; Liu et al., 2017). In the rainy season, however, the monthly runoff in plots with litter was significantly similar to plots with bare soil (Table 1).

The similarity observed in the surface runoff between the plots with and without litter during the rainy season (January-March and October-December) is determined by two factors that can occur separately or concomitantly: the first is that during the wet season, microbial activity accelerates the decomposition of litter, causing a gradual reduction in soil cover, consequently, there is no difference between treatments (Selle, 2007; Liu et al., 2017); the second explanation is that the litter layer not yet decomposed, being saturated by the rains, favors surface runoff by directing the retained water, mainly on the surface of dead leaves, to the runoff collection gutter, preventing it from infiltrating the soil (Li et al., 2014; Lorenzon et al., 2015).

The cumulative pattern of surface runoff during the dry season showed a lower growth rate in plots with litter and a more pronounced increase in plots with bare soil, being 1.6 times greater in plots of soil without litter (Figure 5A). This result is similar to that reported in agroforestry systems in which litter plots reduced 1.7 times the surface runoff in relation to the bare soil (Liu et al., 2017). The litter protects the soil surface from the kinetic energy of the rain, resulting in low accumulation of surface runoff, as reported in cypress forests in Japan (Miyata et al., 2009).

The monthly values evinced a positive correlation between the occurrence of surface runoff and precipitation for both treatments (Figures 4 and 5B). Higher rainfall-surface runoff correlation and greater slope of the regression line were obtained in plots with bare soil. The litter plots showed less
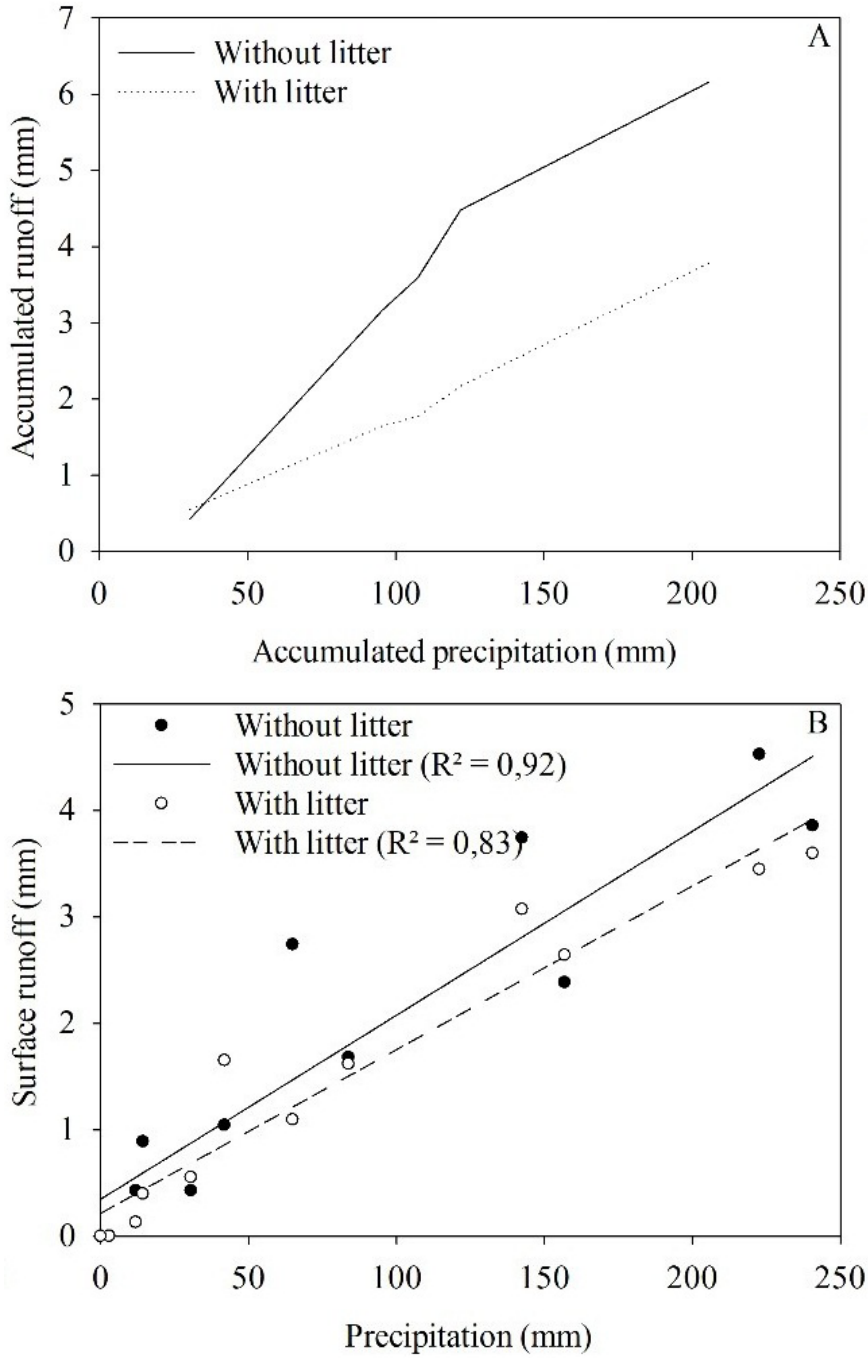

Figure 5. Surface runoff and precipitation in the dry period, between April and September (A) and relationships between runoff and rainfall for plots with and without litter (B).

inclination and a low correlation between precipitation and runoff (Figure 5B).

The positive correlation between surface runoff and precipitation shows that the months with the highest rainfall also showed higher runoff. The presence of litter provided a lower rate of surface runoff with the accumulated precipitation in the present work. The same was verified in the litter of the species of the Jiu Feng National Forest Park in China where runoff decreased dramatically when litter mass increased and proved that the litter cover had a strong impact in reducing surface runoff (Li et al., 2014).

\section{Conclusion}

The presence of litter has reduced surface runoff in a forest fragment in the early stages of regeneration in the Atlantic Forest. This result confirms that the litter has a significant impact on runoff control because its presence at the soil surface intersects the impact of rain and allowing more time for water infiltration into the soil. 
Our results improved the understanding of litter as a protective and redistributing layer of rain.

\section{Acknowledgments}

To the Universidade Federal de Viçosa (UFV), Fundação de Amparo à Pesquisa do Estado de Minas Gerais (FAPEMIG), Coordenação de Aperfeiçoamento de Pessoal de Nível Superior (CAPES) and Conselho Nacional de Desenvolvimento Científico e Tecnológico (CNPq).

\section{Compliance with Ethical Standards}

Funding: Fundação de Amparo a Pesquisa do Estado de Minas Gerais (FAPEMIG), Conselho Nacional de Desenvolvimento Científico e Tecnológico (CNPq), and Coordenação de Aperfeiçoamento de Pessoal de Nível Superior - Brasil (CAPES).

Conflict of interest: The authors declare that there is no conflict of interest (professional or financial) that could influence the article.

Author contribution: Conceptualization: HCTD, AGS, LJS; Data curation: AGS, LJS, SGB, RAB, HCTD; Formal analysis: AGS, LJS, HCTD; Funding acquisition: HCTD; Investigation: AGS, LJS, SGB, RAB, HCTD; Methodology: HCTD, AGS, LJS; Project administration: HCTD; Resources: HCTD; Supervision: HCTD; Validation: AGS, LJS, SGB, RAB, HCTD; Visualization: AGS, LJS, SGB, RAB, HCTD; Writing - original draft: AGS, LSS; Writing review \& editing: AGS, LJS, SGB, RAB, HCTD.

\section{Literature Cited}

Abraham, J.; Dowling, K.; Florentine, S. Risk of post-fire metal mobilization into surface water resources: A review. Science of the Total Environment, v. 599-600, n. 12, p. 1740-1755, 2017. https://doi.org/10.1016/j.scitotenv.2017.05.096.

Ali, A.; Naeem, M.; Dar, T. A.; Idrees, M.; Khan, M. M.; Uddin, M. Nutrient Uptake, Removal, and Cycling in Eucalyptus Species. Essential Plant Nutrients, v. 1, n. 8, p.37-45, 2017. https://doi. org/10.1007/978-3-319-58841-4_2.

Alvares, C. A.; Stape, J. L.; Sentelhas, P. C.; Gonçalves, J. L. M.; Sparovek, G. Köppen's climate classification map for Brazil. Meteorologische Zeitschrift, v. 22, n. 6, p. 711-728, 2013. https:// doi.org/10.1127/0941-2948/2013/0507.

Baptista, J.; Levien, R. Métodos de preparo de solo e sua influência na erosão hídrica e no acúmulo de biomassa da parte aérea de Eucalyptus saligna em um cambissolo háplico da depressão central do Rio Grande do Sul. Revista Árvore, v. 34, n. 4, p. 567575, 2010. https://doi.org/10.1590/S0100-67622010000400001.

Blow, F. E. Quantity and Hydrologic Characteristics of Litter under Upland Oak Forests in Eastern Tennessee. Journal of Forestry, v. 53, n. 3, p. 190-195, 1955. https://doi.org/10.1093/jof/53.3.190.

Burch, G. J.; Moore, I. D.; Burns, J. Soil hydrophobic effects on infiltration and catchment runoff. Hydrological Processes, v. 3, n. 3, p. 211-222, 1989. https://doi.org/10.1002/hyp.3360030302.
Cesarano, G.; Incerti, G.; Bonanomi, G. The influence of plant litter on soil water repellency: insight from $13 \mathrm{C}$ NMR spectroscopy. PLOS ONE, v. 11, n. 3, e0152565, 2016. https://doi.org/10.1371/ journal.pone.0152565.

Coelho, C. O. A.; Laouina, A.; Regaya, K.; Ferreira, A. J. D.; Carvalho, T. M. M.; Chaker, M.; Naafa, R.; Naciri, R.; Boulet, A. K.; Keizer, J. J. The impact of soil water repellency on soil hydrological and erosional processes under Eucalyptus and evergreen Quercus forests in the Western Mediterranean. Soil Research, v. 43, n. 3, p. 309, 2005. https://doi.org/10.1071/SR04083.

Dias, A. T. C.; Cornelissen, J. H. C.; Berg, M. P. Litter for life: assessing the multifunctional legacy of plant traits. Journal of Ecology, $v$. 105 , n. 5, p. 1163-1168, 2017. https://doi.org/10.1111/13652745.12763.

Fundação Estadual do Meio Ambiente - FEAM. Banco de solos de Minas Gerais. http://www.feam.br/noticias/1/949-mapas-desolo-do-estado-de-minas-gerais. 01 Jun. 2019.

Gerrits, A. M. J.; Pfister, L.; Savenije, H. H. G. Spatial and temporal variability of canopy and forest floor interception in a beech forest. Hydrological Processes, v. 24, n. 21, p. 3011-3025, 2010. https://doi.org/10.1002/hyp.7712.

Gomyo, M.; Kuraji, K. Effect of the litter layer on runoff and evapotranspiration using the paired watershed method. Journal of Forest Research, v. 21, n. 6, p. 306-313, 2016. https://doi. org/10.1007/s10310-016-0542-5.

Instituto Nacional de Meteorologia - INMET. Normais climatológicas do Brasil 1981-2010, precipitação acumulada mensal e anual (mm). Planilha eletrônica. http://www.inmet.gov.br/portal/ index.php?r=clima/normaisClimatologicas. 01 Jun. 2019.

Li, X.; Niu, J.; Xie, B. Study on Hydrological Functions of Litter Layers in North China. PLOS ONE, v. 8, n. 7, e70328, 2013. https://doi. org/10.1371/journal.pone.0070328.

Li, X.; Niu, J.; Xie, B. The Effect of Leaf Litter Cover on Surface Runoff and Soil Erosion in Northern China. PLOS ONE, v. 9, n. 9, e107789, 2014. https://doi.org/10.1371/journal.pone.0107789.

Liu, J.; Coomes, D. A.; Hu, G.; Liu, J.; Yu, J.; Luo, Y.; Yu, M. Larger fragments have more late-successional species of woody plants than smaller fragments after 50 years of secondary succession. Journal of Ecology, v. 107, n. 2, p. 582-594, 2019. https://doi. org/10.1111/1365-2745.13071.

Liu, W.; Luo, Q.; Lu, H.; Wu, J.; Duan, W. The effect of litter layer on controlling surface runoff and erosion in rubber plantations on tropical mountain slopes, SW China. Catena, v. 149, n. 1, p. 167175, 2017. https://doi.org/10.1016/j.catena.2016.09.013.

Lorenzon, A. S.; Dias, H. C. T.; Tonello, K. C. Escoamento Superficial da Água da Chuva em um Fragmento Florestal de Mata Atlântica, Viçosa-MG. Revista Brasileira de Agropecuária Sustentável, v. 5, n. 1, p. 50-58, 2015. https://doi.org/10.21206/rbas.v5i1.316.

Marcilio-Silva, V.; Zwiener, V. P.; Marques, M. C. M. Metacommunity structure, additive partitioning and environmental drivers of woody plants diversity in the Brazilian Atlantic Forest. Diversity and Distributions, v. 23, n. 10, p. 1110-1119, 2017. https://doi. org/10.1111/ddi.12616.

Marin, C. T.; Bouten, I. W.; Dekker, S. Forest floor water dynamics and root water uptake in four forest ecosystems in northwest Amazonia. Journal of Hydrology, v. 237, n. 3-4, p. 169-183, 2000. https://doi.org/10.1016/S0022-1694(00)00302-4. 
Mateus, F. A.; Miranda, C. C.; Valcarcel, R.; Figueiredo, P. Estoque e capacidade de retenção hídrica da serrapilheira acumulada na restauração florestal de áreas perturbadas na Mata Atlântica. Floresta e Ambiente, v. 20, n. 3, p. 336-343, 2013. https://doi. org/10.4322/floram.2013.024.

Miller, S. Handbook for agrohydrology. Chatham: Natural Resources Institute, 1994. 280p.

Miyata, S.; Kosugi, K.; Gomi, T.; Mizuyama, T. Effects of forest floor coverage on overland flow and soil erosion on hillslopes in Japanese cypress plantation forests. Water Resources Research, v. 45, n. 6, p. 1-17, 2009. https://doi.org/10.1029/2008WR007270.

Muñoz, Á. G.; Thompson, M. C.; Goddard, L.; Aldighieri, S. Analyzing climate variations at multiple timescales can guide Zika virus response measures. GigaScience, v. 5, n. 1, s13742-016-0146-1, 2016. https://doi.org/10.1186/s13742-016-0146-1.

Park, A.; Friesen, P.; Serrud, A. A. S. Comparative water fluxes through leaf litter of tropical plantation trees and the invasive grass Saccharum spontaneum in the Republic of Panama. Journal of Hydrology, v. 383, n. 3-4, p. 167-178, 2010. https://doi. org/10.1016/j.jhydrol.2009.12.033.

Pinto, S. I. C.; Martins, S. V.; Moretti, B. C. Composição florística do componente arbustivo-arbóreo em dois trechos de floresta estacional semidecidual na Mata do Paraíso, Viçosa, MG. Revista Agrogeoambiental, v. 5, n. 2, p. 11-24, 2013. https://doi. org/10.18406/2316-1817v5n22013433.
R Core Team. R: a language and environment for statistical computing. Vienna: R Foundation for Statistical Computing, 2018.

Selle, G. L. Ciclagem de nutrientes em ecossistemas florestais. Bioscience Journal, v. 23, n. 4, p. 29-39, 2007. http://www.seer. ufu.br/index.php/biosciencejournal/article/view/6912. 29 Mar. 2020.

Silva Júnior, W. M. et al. Regeneração natural de espécies arbustivo-arbóreas em dois trechos de uma Floresta Estacional Semidecidual, Viçosa, MG. Scientia Forestalis, v. 66, n. 17, p. 169-179, 2004. https://www.ipef.br/publicacoes/scientia/ nr66/cap17.pdf. 19 Mar. 2020.

Vogelmann, E. S.; Prevedello, J.; Reichert, J. M. Origem dos compostos hidrofóbicos e seus efeitos em florestas de Pinus e Eucalyptus. Ciência Florestal, v. 25, n. 4, p. 1067-1079, 2015. https://doi.org/10.5902/1980509820670.

Walsh, R. P. D.; Voigt, P. J. Vegetation Litter: An Underestimated Variable in Hydrology and Geomorphology. Journal of Biogeography, v. 4, n. 3, p. 253-274, 1977. https://doi. org/10.2307/3038060.

World Meteorological Organization - WMO. Measurement of precipitation. In: World Meteorological Organization - WMO (Ed.). Part I. Measurement of meteorological variables. Geneva: WMO, 2018. Chap. 6, p.186-219. https://library.wmo.int/doc_ num.php?explnum_id=3152. 29 Mar. 2020. 